\title{
IDENTIFICATION OF YOUNG TALENTS IN SPORT
}

\author{
Milan Žvan, Milan Čoh \\ Faculty of Sport, University of Ljubljana, Slovenia
}

\begin{abstract}
Summary. Identification of sport talented individuals and their timely introduction into the training process of a sport that corresponds the most to their abilities is one of the most demanding procedures in the modern sport science. Wrong decisions are frequent and usually very painful. The problem of talented individuals is in the fact that they are not talented only in one area but they are, as a rule, successful in many areas. The basic dilemma is related to the decision about which sports to engage in and how much time to devote to a specialized sport. Is early engagement of children in sport useful or not? The answer is yes and no. However, early engagement in sport has become trendy in contemporary sport. Many young champions burn out too soon. Coaches and too ambitious parents often have completely unrealistic expectations about the sport results of their children. Due to oversized and extremely specialized training, on average young athletes sustain injuries relatively frequently and also lack internal motivation.
\end{abstract}

Key words: selection sport, talent, motivation, elite sport.

\section{Introduction}

Sport results depend on various factors which arise from an athlete or his or her environment. Genetic potential of athletes and their development, an adequate and systematic training process, high level of motivation, pedagogic and professional work are the key factors to success in sport. Selectivity is one of the main characteristics of sport. Initial selection- talent identification is a universal interdisciplinary field of genetics, kinesiology, biomechanics, sport medicine, physiology and developmental psychology. Initial selection is closely related to gifttalent of an individual. Who is gifted, who talented? Giftedness is a wider term, talent narrower. Gifted students are those who show great success in various fields. Talented students are those who show great potential and success in one field. (George, 1997, Jurak, 2005; Ericsson, 2007; Baker et al., 2012). How to recognize a gifted-talented child or student? How giftedness is manifested, and how talent, which instruments and tests are used to identify gifted-talented children, do we generally recognize true sports talent? How to recognize talent for a certain sport? These are typical questions to which kinesiology as a science does not have completely clear answers. Identification and development of sport talent is a complex issue on which many authors have different views (Bompa, 2000; Balyi, 2002; Vaeyens, Matthieu, Williams, Philippaerts, 2008, Baker et al., 2012; Epstein, 2015, Skof, 2016).

\section{Talent in sport}

Talent in sport is defined by genetically innate morphological features, psycho-motor and functional abilities, cognitive and social characteristics, as well as motivation. The development and realization of these abilities to a great extent depend on parents, school,

Autor za korespondenciju: Milan Čoh, e-mail: milan.coh@fsp.uni-lj.si

Faculty of Sport, University of Ljubljana, Gortanova 22, 1000 Ljubljana, Slovenia

Primljeno u redakciju 20. 8. 2018, rad prihvaćen za publikovanje 3. 9. 2018. 
sports club, a coach, immediate and wider social environment (Renzulli, 1986). Authors J. Baker, S. Cobley, and J.Schorer in their book Talent Identification and Development in Sport define talent in soccer according to 4 groups of predictors: anthropometric predictor, physiological-motor predictors, psychological and social predictors.

According to Malina (2010) talent in sport is a combination of above average bio-motor skills, creativity and inner motivation. Talented children have several traits in common. These are the following: they exhibit similar behavior, environment is the key to realization of their potential, if they are not properly motivated they lose interest in developing their gift, they experience the world around them differently, their needs are different, it is a great challenge to work with them, and a great strain for their parents, teachers and coaches as well. Finally, talented children deserve talented, capable and coaches and teachers who demonstrate emphaty!

\section{Identification of young talents in sport}

The problem of talent identification of children for sport is very complex. Talented children as a rule display above average abilities in different domains. Sport is just one possible choice for them. Is it useful to encourage talented children to take up general and individual sports!? Is early specialization useful? Sport practice does not offer clear answers. The problem of 'young champions' is that they 'burn out' soon, they lack motivation, get injured or get tired of excessive training. The results in the early stage of their development are not a guarantee of success in their sports career later in life. Many talented individuals finish their career due to the inadequate, monotonous and excessive training, which as a consequence leads to injury and lack of inner motivation. On the other hand, some athletes start doing sport later in their lives and they achieved top results.

There are different methods of identification and selection of talented children in sport. The most simple and most basic is a method of natural selection. According to this method selection of children is based on current results in competitions. These results can be the consequence of different training quantity and intensity. Sport results can also be the consequence of faster biological maturity and not talent itself. There may be a gap of two or more years between the calendar and biological age. This method has proven to be unreliable. Biological age can be a great advantage or disadvantage for a young athlete. Biological age generates motor skills potential which is manifested through results on competitions.

Another group of identification and selection methods belong to scientific methods. There are several international methods. The most famous are the following (Skof, 2016):

- Talent Identification and Development Programs in Sport (TIDPS)

- Talent Intelligence, Personality, Skills - TIPS

- Speed, Understanding, Personality - SUPS

- Differentiated Model of Giftedness and Talent - DMGT

- Talent - SLO

We should point out the fact that even these methods are not highly reliable. There is no such method which could predict results in mature age of an athlete for certain. This only proves the fact that identification, selection and prediction in sport is a complex problem. Success in sport depends on various internal and external factors. The combination of motor skills, psychological factors cognitive abilities, biological and psycho-social development has a great influence on the pace and dynamic of progress of an individual. This only indicates to which extent man is a complicated biological machine, influenced by unpredictable principles. 


\section{Children specialization in sport}

The question of whether it is useful and necessary to encourage children to do sport at an early age is often asked. There is a wide range of examples of negative practice. Early specialization does not necessarily lead to expected positive results. Many talented children who achieved great results in certain sport at an early age, could not repeat those results later in life. There are certain exceptions to the rule. Tiger Woods started playing golf at the age of three, Novak Djokovic started playing tennis at the age of 4, and Andre Agassi started beating his peers at the age of 6 . Early involvement in sport is a world trend. Competitiveness between various sports for young talented athletes is great. Early sport specialization is linked to specific training process and pressure. The consequences of such a training are injures in young athletes. Early specialization means pressure of the environment, coach and parents to achieve great results. This puts a lot of pressure, responsibility and stress on a young athlete. The coach and parents often have unrealistic expectations from their children concerning success. When it is imperative to succeed and win, then the training has to be intensive, specialized and monotonous which as a consequence sooner or later leads to injuries and satiety with training and sport itself. This is a technical mistake, young athletes should experience the training and competition both rationally and emotionally. Monotonous training does not bring to the development of thorough preparation of motor skills, which is the basis for specific training. It is not an issue if children start practicing sport at an early age, but the fact that such an activity prevents them from engaging in spontaneous activities with their peers. If a child is overwhelmed during the period of greatest growth and development, he or she will not be able to reach the optimal height, at the same time other systems will not be able to function properly (Baker et al., 2012).

Negative factors of early specialization are the following:

- Social isolation - segregation of young athletes

- Excessive dependence on sport results

- Psychological stress

- Burn out syndrome and over-exhaustion

- The lack of possibility for education

- Manipulation of a coach and parents regarding the goals to be achieved

- The lack of inner motivation for training and competitions

- Being bored of sport syndrome

- Endangering development and health of a young athlete

- Micro injuries and specific injuries

\section{Models of young athletes development}

The path to top sport results is a long, difficult and uncertain one. On average, the process lasts $8-10$ years, which means about 10.000 hours of training. The author of this theory is a Swedish physiologist, Anders Ericsson. The theory has a lot of supporters and opponents. Models of athlete development vary regarding the aspect of specific sports. Besides the classical model of athlete development with an early specialization, the so called divergent model with later specialization is more and more applied. According to this model at the beginning a broad multidimensional training is applied which includes (Bompa, 2000), various types of exercises, different sports, development of basic motor and functional skills. The stress is on a human, holistic approach to a training process of a child. Training has to be a game based on motivation and positive emotions. (Bompa, 2000; 
Malina, 2010, Skof, 2016). Divergent method is based on modern principles of neurophysiology of child nervous system development. Intellectual and motor development of a child is the most intensive in the period between 4 and 12 years of age.

One of the most famous models of a long-term functional development of athletes is the Canadian model, by the author I. Balya (Figure 1). The model consists of five phases of the athlete development:

1. Game phase - basic exercises (Fundamentals)

2. Learning phase (Learning to Train)

3. Basic sport preparation for a certain sport phase (Learn to Train)

4. Competition preparation phase (Training to Compete)

5. Training for the achievement of top results phase (Training to Win)

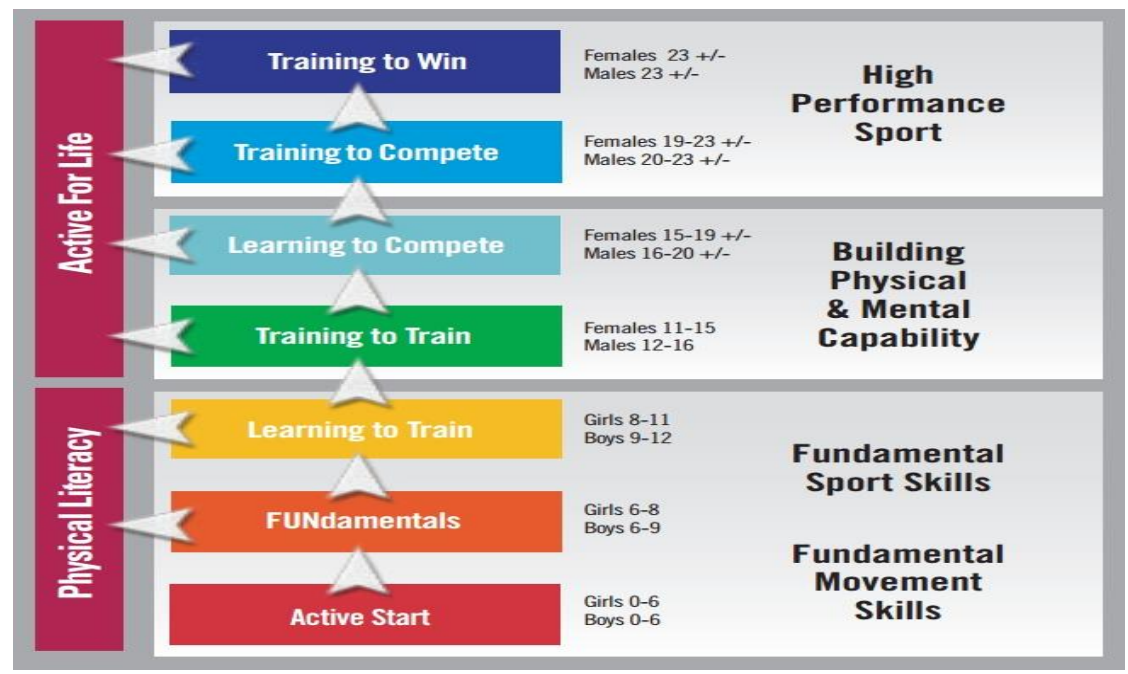

Figure 1. Model of a long-term sport development (Balyi, 2002)

\section{Conclusion}

Early specialization in sport means monotonous, intensive, competition-oriented training for young athletes. Winning is the imperative, and the consequence is a comprehensive, specific training which jeopardizes health and normal functional development of athletes in the long run. Specific exercises in early childhood do not fulfil social needs of children. American Pediatric Academy warns that children who do only one sport are deprived of many motor and psycho-social skills (Skof, 2016). Specialization, great ambitions of the coach and parents, subject young athletes to a lot of pressure, stress and social isolation. Sport is no longer just a game, but great burden which creates fear of a failure. A young athlete cannot build up confidence, develop creativity and nurture ambition because of the great responsibility and fear. Failure damages ego and decreases enjoyment in sport. The adjustment to school curriculum and obligations, and social isolation often end a sport career. 


\title{
References
}

Balyi I. (2002). Long - term athlete development: http://coac-hing. Usolympicteam.com

Baker, J., Cobley, S., Schorer, J.(2012). Talent identification and development in sport«. Routledge, Taylor \& Francis Droup.

Bompa, T. (2000). Total trening for young champions. Human Kinetics. Champaign, IL.

Epstein, D. (2015). Športni gen. Talent, trening in resnica o uspehu. UMco, Ljubljana 2015.

Ericsson, A. (2007). Deliberate practice and the modifiability of the body and mind: Toward a science of the structure and acquisition of expert and elite performance. International Journal of Sport Psychology, 38, 4-34.

Eynon, N., Hanson E., Lucia, A, Houweling, P., Garton F, North, K., Bishop, J. (2013). Genes for elite power and sprint performance: ACTN3 leads the way. Sports medicine, 43 (9), 803-817.

Jurak, G. (2005). Športno nadarjeni otroci in mladina v slovenskem šolskem sistemu. Annales, Univerza na Primorskem, Znanstveno-raziskovalno središče Koper.

Malina, R. (2010). Early Sport Specialization : Roots; Effectiveness, Risks. Current Sports Medicine Reports, Vol. 9, No. 6, 364-371.

Rajović, R. (2015). IQ otroka - skrb staršev. Mensa Slovenije, Ljubljana

Renzulli, J. (1986). The three-ring conception of giftdness: a developmental model for creating productivity. Conceptions of gifttedness. London, Cambridege University Press.

Skof B. (2016) Šport po meri otrok in mladostnikov. Fakulteta za šport, Ljubljana.

Vaeyens, R., Matthieu, L.,Mark Williams, M., Philippaerts, M.(2008). Talent Identification and Development Programmes in Sport Current Models and Future Directions. Sport Medicine, 38 (9), 703-714.

\section{IDENTIFIKACIJA MLADIH TALENATA U SPORTU}

\author{
Milan Žvan, Milan Čoh
}

Sažetak. Identifikacija talentovanih pojedinaca u sportu i njohovo uključivanje u trenažni proces sporta koji najviše odgovara njihovim sposobnostima na vreme predstavlja jednu od najzahtevnijih procedura u nauci savremenog sporta. Pogrešne odluke su česte i veoma bolne. Problem vezan za talentovane osobe leži u činjenici da one ne ispoljavaju talenat u okviru jedne oblasti, već po pravilu, postižu uspehe u različitim oblastima. Glavna nedoumica vezana je za to kojim sportom se treba baviti i koliko vremena treba posvetiti određenom sportu. Da li je rano uključivanje dece u sport korisno ili ne? Odgovor je da i ne. Međutim, rano bavljenje sportom postalo je trend u savremenom sportu. Mnogi mladi šampioni prerano sagore. Treneri i preambiciozni roditelji često imaju potpuno nerealna očekivanja u pogledu sportskih rezultata svoje dece. Kao posledica preteranog i previše usmerenog treninga, mladi sportisti u proseku često podležu povredama i često im nedostaje unutrašnja motivacija.

Ključne reči: izbor sporta, talenat, motivacija, elitni sport. 